УДК 339.

https://doi.org/10.52058/2708-7530-2021-9(15)-285-296

Зеліч Вікторія Вікторівна кандидат економічних наук, доцент, доцент кафедри бізнес-адміністрування, маркетингу та менеджменту, Ужгородський національний університет, пл. Народна, 3, м. Ужгород, 88000, тел.: (050) 540-63-51, e-mail: viktoria982@gmail.com, https://orcid.org/0000-0002-3494-1226

Свтухова Світлана Миколаївна кандидат економічних наук, доцент, доцент кафедри економіки, менеджменту та адміністрування, Херсонський державний університет, вул. Університетська, 27, Херсон, 73000, тел.: (067) 76807-30, e-mail: s.evtoukhova@gmail.com, https://orcid.org/0000-0001-7521-8459

Гречаник Олена Свгенівна кандидат економічних наук, доцент, завідувач кафедри наукових основ управління, Харківський національний педагогічний університет імені Г. С. Сковороди, вул. Валентинівська, 2, Харків, 61168, тел.: (096) 194-05-03, e-mail: grechaniklena@ukr.net, https://orcid.org/0000-0002-4671-0724

\title{
АНАЛІЗ ПОКАЗНИКІВ КОМУНІКАТИВНОГО МЕНЕДЖМЕНТУ ПІДПРИЕМСТВА ПРИ ЗДІЙСНЕННІ МАРКЕТИНГОВОГО АУДИТУ
}

Анотація. У статті досліджено особливості та механізми показників комунікативного менеджменту підприємства та управління маркетингом підприємства на ринку в умовах бізнес-середовища. Створення умов для успішного функціонування комунікацій в організації становить одне 3 найважливіших завдань управління. Комунікація є життєво важливою системою організації: якщо якимось чином ліквідувати потоки повідомлень в організації, то вона припинить своє існування. Окреслено основні напрями маркетингового аудиту комунікаційної політики підприємства. Визначено основні риси, характерні для аудиту маркетингової діяльності. Досліджено основні компоненти комплексного аудиту маркетингової діяльності. Проведена систематизація цілей маркетингу та комунікативної діяльності підприємства. Визначено значення інструментів маркетингових комунікацій при просуванні споживчих товарів і товарів виробничого призначення. Проаналізовано результативність комунікацій в організації та результати комунікаційної кампанії в цілому. Аудит маркетингу представлений як системний процес всебічного аналізу ефективності роботи комплексу маркетингу підприємства. Під системним підходом до проведення аудиту маркетингу розуміють наявність i послідовність проведення адміністративних і аналітичних процедур, методів отримання аудиторських доказів за допомогою організації інформаційних потоків отримання необхідної інформації. Отримані в роботі результати, висновки та сформульовані пропозиції 
$\epsilon$ певним внеском у розвиток теорії і практики управління підприємствами i, зокрема, управління ефективністю їх комунікативної маркетингової діяльності. Використання в практичній діяльності маркетологів результатів проведеної класифікації теоретико-методичних підходів до системної оцінки ефективності комунікативного менеджменту підприємства підвищить рівень наукової обгрунтованості прийнятих рішень в сфері управлінського маркетингу.

Ключові слова: комунікативний менеджмент, аудит, аналіз, маркетингова діяльність, комунікація, маркетингові дослідження; стратегія маркетингу.

Zelich Victoria Viktorivna Candidate of Economic Sciences, Associate Professor, Associate Professor of the Department of Business Administration, Marketing and Management, Uzhhorod National University, Narodna Pl., 3, Uzhhorod, 88000, tel.: (0500 540-63-51, e-mail: viktoria982@gmail.com, https://orcid.org/00000002-3494-1226

Yevtukhova Svitlana Mykolayivna Candidate of Economic Sciences, Associate Professor, Associate Professor of the Department of Economics, Management and Administration, Kherson State University, University St., 27, Kherson, 73000, tel.: (067) 768-07-30, e-mail: s.evtoukhova@gmail.com, https://orcid.org/0000-0001-7521-8459

Grechanyk Olena Yevhenivna Candidate of Economic Sciences, Associate Professor, Head of the Department of Scientific Fundamentals of Management, H.S. Skovoroda Kharkiv National Pedagogical University, Valentinovskaya St., 2, Kharkiv, 61168, tel.: (096) 194-05-03, e-mail: grechaniklena@ukr.net, https://orcid.org/0000-0002-4671-0724

\section{ANALYSIS OF INDICATORS OF COMMUNICATIVE MANAGEMENT OF THE ENTERPRISE DURING MARKETING AUDIT}

Abstract. The article examines the features and mechanisms of indicators of communicative management of the enterprise and marketing management of the enterprise in the market in a business environment. Creating conditions for the successful functioning of communications in the organization is one of the most important tasks of management. Communication is a vital system of the organization: if you somehow eliminate the flow of messages in the organization, it will cease to exist. The main directions of marketing audit of the communication policy of the enterprise are outlined. The main features characteristics of the audit of marketing activities are identified. The main components of a comprehensive audit of marketing activities are studied. The systematization of the purposes of marketing and communicative activity of the enterprise is carried out. The importance of marketing communication tools in the promotion of consumer goods and industrial goods is determined. The effectiveness of communications in the organization and the results of the communication campaign 
as a whole are analyzed. Marketing audit is presented as a systematic process of comprehensive analysis of the effectiveness of the marketing complex of the enterprise. Under the systematic approach to marketing audit understand the presence and sequence of administrative and analytical procedures, methods of obtaining audit evidence by organizing information flows to obtain the necessary information. The results, conclusions and formulated proposals obtained in the work are a certain contribution to the development of the theory and practice of enterprise management and, in particular, the management of the effectiveness of their communicative marketing activities. The use in the practice of marketers of the results of the classification of theoretical and methodological approaches to the systematic assessment of the effectiveness of communicative management of the enterprise will increase the level of scientific validity of decisions in the field of management marketing.

Keywords: communicative management, audit, analysis, marketing activities, communication, marketing research; marketing strategy.

Постановка проблеми. Зростання витрат на маркетинг зумовило проблему аналізу ефективності та аудиту маркетингової діяльності. Використання маркетингового підходу дозволило виявити основні етапи розвитку. В сучасних умовах маркетинговий аудит розглядається як важливий інструмент оцінки ефективності маркетингу. У зв'язку з цим визначені основні етапи аудиту маркетингової діяльності та утримання робочих документів.

Діяльність будь-якої організації спрямована на досягнення поставлених перед нею цілей. Ці цілі є вихідним моментом при розробці планів і програм маркетингу, процес виконання яких повинен забезпечити точне просування до установлених меж. Оцінка ступеня відповідності установлених цілей i маркетингових програм забезпечується за допомогою маркетингового контролю або маркетинг-аудиту.

Система аудиту маркетингу передбачає здійснення окремих видів контролю, призначених для спостереження і оцінки ефективності діяльності організації, виявлення всіх недоліків і вжиття відповідних заходів щодо їх усунення. Контроль результатів спрямований на встановлення збігу або відповідності основних запланованих показників реально досягнутим результатам з економічних (збут, частка ринку) і не економічних (відношення споживачів) об'єктів маркетинг-аудиту.

Аналіз останніх досліджень і публікацій. Зарубіжні вчені-фахівці в області маркетингу Ф. Котлер і К. Келлер наводять показники (метрики) ефективності маркетингу по відношенню до зовнішнього і внутрішнього середовища $[5$, с. 145148]. Можна вважати, що ці вчені більшою мірою наблизилися до розробки алгоритму розрахунку оціночного показника ефективності маркетингу, проте не довели його до рівня практичного застосування (не розроблені шкали для якісної оцінки маркетингу і модель розрахунку інтегрального показника ефективності). 
В основі методологічного підходу до оцінки ефективності маркетингу, на думку російського вченого Г. Яшевої, лежить оцінка виконання функцій маркетингу і функцій управління маркетингом за допомогою експертних оцінок. При цьому формування системи оцінки ефективності маркетингу базується на використанні результатів проведення анкетування [7].

Науковці Г. Плеханова і О. Китова в своїх роботах, присвячених проблемам управління корпоративною ефективністю (Corporate Performance Management, СРМ), на основі методології ціннісно-орієнтованого і цільового управління корпорацією, розглядають такий напрямок як управління ефективністю маркетингу (Marketing Performance Management) [6].

Проблеми комунікацій в системі управління підприємствами розглядаються різними напрямками управлінської думки. Основною увагою ці проблеми користуються в зарубіжних дослідженнях А. Файоля, Ф. Тейлора, Е. Мейо, Г. Саймона, К. Ясперса, I. Річардса та ін. Також проблемам теорії і практики комунікаційних процесів приділено чималу увагу i в роботах вітчизняних фахівців та вчених, серед яких В. Кошкін, І. Кириченко, В. Лавриненко, С. Самигін, Л. Столяренко.

Мета статті полягає у дослідженні особливостей та механізмів показників комунікативного менеджменту підприємства та управління маркетингом підприємства на ринку в умовах бізнес-середовища.

Виклад основного матеріалу. Комунікації як обов'язкову складову частину менеджменту стали розглядати в рамках стратегічного управління організацією, коли з'ясувалося, що сучасний бізнес залежить не тільки від економічних, але i від ряду інших факторів, залежних від добре налагодженої в організації комунікації.

Для ефективного просування товару на ринок ключовим $є$ формування відповідного ставлення до товару споживачів і відповіді за реалізацію агентів і дилерів, що також неможливо без ефективної системи комунікації [2].

Таким чином, управляти комунікацією - це значить: визначати цілі комунікації; визначати шляхи досягнення цих цілей і конкретні дії, спрямовані на досягнення цілей; організувати здійснення цих комунікативних дій; координувати взаємодію комунікаторів; контролювати; коригувати процес за результатами комунікації.

Відправним пунктом в розвитку теорії маркетингового аудиту можна вважати публікацію Ф. Котлера та його співавторів «The Marketing Audit Comes of Age» [1], де вони стверджували, що маркетинговий аудит є етапом процесу планування маркетингу. На думку дослідників, маркетинговий аудит також можна розглядати як інструмент контролю розвитку організації в ринковому середовищі.

Іноді для проведення ефективної комунікаційної політики необхідно проводити великі рекламні кампанії, іноді потрібні невеликі PR, реклама або промоакції, іноді досить регулярних зустрічей 3 представниками цільових 
аудиторій, іноді необхідно створювати і реалізовувати спільні проекти [4].

Основними напрямками маркетингового аудиту комунікаційної політики підприємства $\epsilon$ аудит ефективності використання таких засобів як реклама; зв'язки 3 громадськістю; стимулювання збуту; прямий маркетинг; участь у виставках; персональний продаж; спонсорська діяльність; інтегровані маркетингові комунікації.

Як і будь-які інші взаємини, стратегічні партнерські взаємини не можуть бути налагоджені моментально. Необхідна системна робота по налагодженню і підтримці таких відносин, яка складається в тому числі з постійного аналізу цільових аудиторій і ключових персон, аналізу зміни моделей мислення цих цільових аудиторій, розробки способів і каналів налагодження і підтримки взаємин, відстеження зворотного зв'язку.

Аналіз маркетингових витрат включає три етапи:

1. Вивчення бухгалтерської та іншої внутрішньої звітності, порівняння надходжень від продажів і валового прибутку з поточними витратами.

2. Перерахунок витрат за функціями маркетингу: витрати на маркетингові дослідження, рекламу, планування і контроль, тобто зв'язуються поточні витрати 3 конкретною маркетинговою діяльністю.

3. Розбивка функціональних витрат по окремих товарах, методах і формах реалізації, збутових територіях, ринкових сегментах і т.д.

Відповідно, ефективність маркетингової комунікаційної діяльності залежить від: величини бюджету на комунікаційні заходи; аналізу характеристик цільового сегмента ринку і його ментальних особливостей; знання і володіння методиками комунікаційної діяльності; термінів, часу здійснення комунікативного впливу; швидкості, оперативності комунікативного поводження [3].

Грамотне управління комунікаціями здатне значно підвищити економічну ефективність суб'єкта на основі конкретного механізму впливу на ключові параметри діяльності: техніко-економічні показники, ділову активність, інвестиційну привабливість і коефіцієнти ефективності управління, а в цілому на динаміку розвитку економічної системи і ступінь реалізації організаційного потенціалу. При цьому ефективне управління комунікаціями створює умови для виходу на новий етап розвитку, підвищення конкурентоспроможності та досягнення поставлених цілей [2].

В основу аналізу комунікаційного аудиту покладено діяльніснопроцесуальний підхід до комунікації, відповідно до якого комунікативний процес можна розділити на окремі фрагменти. Процес комунікації є безперервною взаємодією учасників цього процесу [4]. Таким чином, аналіз процесу комунікації включає в себе комплекс складових. У заходах, пов'язаних з комунікаціями, задіяні учасники комунікації - комуніканти (відправник і одержувач), що виробляють і інтерпретують повідомлення. Комунікація може бути здійснена вербальними і невербальними засобами.

Головна мета процесу комунікації - забезпечити розуміння інформації, яка $€$ 
предметом обміну. Аудит комунікації - це один із способів, за допомогою якого можна вивчити імідж компанії, так як «будь-яка PR-діяльність повинна починатися з формування позитивного іміджу компанії, а в майбутньому - його моніторингу та вдосконалення» [2].

На думку експертів, однією 3 головних ознак успішної організації майбутнього $є$ прискорення всіх бізнес-процесів - час перетворюється на вирішальний фактор конкурентоспроможності.

А своєчасність і оперативність як управління, так і виконавча діяльність, немислимі без кваліфікованого застосування інструментарію комунікаційного менеджменту. Так само як i інші сфери функціонального менеджменту, комунікаційний менеджмент випливає з цілей і стратегії організації, реалізується в тактичних рішеннях, має свої власні цілі і програми, проекти, бюджет.

Основними завданнями комунікаційного менеджменту на підприємстві $є$ : формування корпоративної спільності колективу і створення відповідної мотивації співробітників; підтримка і розвиток корпоративної культури; корпоративні цінності і норми поведінки; інформаційна підтримка управлінських рішень; комунікаційне управління змінами (реструктуризація компанії, скорочення, освоєння нових технологій, злиття бізнесів), скорочення протидії внесеним змінам; виявлення комунікаційних та управлінських проблем компанії, сприяння попередженню конфліктів в колективі.

Комунікаційний менеджмент спирається на наступні інструменти (названі за напрямками): зв'язки з громадськістю (public relations);

- робота 3 акціонерами, інвесторами і партнерами (investor relations); брендинг; формування іміджу і управління репутацією; зв'язки зі ЗМI (media relations).

Внутрішньоорганізаційні комунікації забезпечують взаємодію з персоналом, комунікації між співробітниками. Завданням взаємодії 3 персоналом $\epsilon$ забезпечення мотивації співробітників до оптимально кращого виконання своєї роботи. Даний напрямок здійснюється фахівцями відділу корпоративних комунікацій спільно з відділом по персоналу.

Комунікативний потік всередині організації (відповідно просторовому розташуванню каналів) може переміщатися у вертикальному і горизонтальному напрямку.

Вертикальний комунікаційний зв'язок, в свою чергу, за спрямованістю спілкування поділяється на спадні і висхідні комунікації. Роль менеджера 3 комунікацій полягає в тому, щоб служити центральною ланкою в системі контролю над комунікаціями в організації, тобто не самому бути комунікатором, а стати менеджером або керівником, навчаючи інших процесу комунікації. Принцип посередництва, що лежить в основі управління комунікаціями, передбачає, що ситуації, в яких такий працівник виступає як комунікатор, досить обмежені. Набагато частіше він діє як проектувальник, контролер, керівник процесів, в яких він сам не бере безпосередньої участі. 3 цієї причини результат 
його діяльності менш очевидний.

Менеджер повинен контролювати не тільки потоки комунікації до персоналу організації, а й потоки, спрямовані на зовнішні аудиторії. У сенсі контролю, здійснюваного менеджерами 3 комунікацій, вища управлінська ланка - це не більше, ніж ще одна група громадськості.

Необхідно відзначити, що під комунікаційним аудитом слід розуміти комплексну оцінку комунікаційної (інформаційної) політики компанії за певний період часу.

План здійснення будь-якого проекту в рамках комунікаційного менеджменту являє собою відповідь на три класичних питання:

1. Що ми маємо? (Where are we now? - аналіз нинішньої ситуації).

2. Що ми хочемо? (Where do we want to be? - роз'яснення цілей і завдань).

3. Як цього досягти? (How do we get there? - вироблення стратегіï).

Основоположними функціями комунікаційного аудиту можна вважати наступні: оцінну (здійснюється оцінка іміджу компанії, іiі комунікаційної активності); управлінсько-стратегічну (на основі отриманих даних розробляється стратегія іміджевого і конкурентного позиціонування організації, відбувається процес коригування в управлінні діловою репутацією організації, брендування товарів і послуг); інформативну (керівники організацій, топ-менеджери отримують репрезентативну інформацію про поточну ситуацію); прогнозну (прогнозується розвиток компанії в коротко-, середньо- і довгостроковій перспективі, приймаються превентивні заходи з антикризового управління) [3].

Комунікації, здійснювані на підприємствах, можуть бути класифіковані за низкою ознак (табл. 1) [5, с. 67].

Таблиия 1

Види комунікацій на підприємствах

\begin{tabular}{|c|c|}
\hline \multicolumn{1}{|c|}{ Ознаки } & Види комунікації \\
\hline Суб'єкт і засоби комунікацій & $\begin{array}{c}\text { Комунікації за допомогою технічних } \\
\text { засобів,інформаційних технологій; міжособистісні }\end{array}$ \\
\hline Форма спілкування & Вербальні; невербальні \\
\hline Канали спілкування & Формальні; неформальні \\
\hline $\begin{array}{c}\text { Організаційна ознака (просторове } \\
\text { розташування каналів) }\end{array}$ & Вертикальні; горизонтальні; діагональні \\
\hline Спрямованість спілкування & Спадна; висхідна \\
\hline
\end{tabular}

В рамках комунікаційного аудиту необхідно зробити акцент на кількох самостійних напрямках діяльності, кожен 3 яких має на увазі наявність спеціальних методів і технологій дослідження: моніторинг інформаційного простору, прес-кліпінг матеріалів; проведення якісних і кількісних соціологічних досліджень; робота 3 документами; контент-аналіз інформаційних матеріалів; робота 3 інсайдерськими джерелами інформації; аналіз інформації, виявлення реального іміджу бізнес-структури; розробка рекомендацій по іміджевому позиціонуванні (формування, коригування та підтримка стратегії формування 
іміджу компаніï) [3].

Таким чином, комунікаційний аудит $\epsilon$ ефективним інструментом для періодичного моніторингу стану різних аспектів іміджу організації, визначення сильних і слабких сторін комунікативної політики організації.

Загальна схема комунікації виглядає таким чином: визначення реального іміджу організації - розробка стратегічного іміджу - меседжі - канали комунікації - засоби комунікаційного впливу - цільові аудиторії.

Першим кроком аналізу процесу формування маркетингових комунікацій $\epsilon$ ідентифікація цілей та стратегій маркетингу та відповідність їх цілям маркетингової комунікаційної політики. Окрім виявлення наявності чітко сформульованих цілей та їх ієрархії по значимості і термінах виконання, аналітик повинен обов'язково з'ясувати наявність наперед заданих критеріїв їх досягнення.

Полегшити роботу 3 виявленням цілей допоможе їх систематизація, яка представлена в табл. 2.

Таблиия 1.2

Цілі маркетингу та комунікативної діяльності підприємства

\begin{tabular}{|c|c|c|}
\hline Цілі маркетингу & $\begin{array}{c}\text { Цілі } \\
\text { маркетингової } \\
\text { комунікативної } \\
\text { діяльності }\end{array}$ & Критерії \\
\hline \multirow{3}{*}{$\begin{array}{l}\bullet \text { Зростання частки ринку (в т.ч. в } \\
\text { регіонів, продуктів і сегментів ринку); } \\
\bullet \text { Збільшення обсягу продажу (в т.ч. в розрізі } \\
\text { регіонів, продуктів, сегментів); } \\
\text { • Підвищення рівня пізнавання та іміджу } \\
\text { підприємства; } \\
\bullet \quad \text { Покращення стану задоволення клієнтів; } \\
\text { • Збільшення маржинального прибутку }\end{array}$} & Інформування & $\begin{array}{ll}20 \% & 3 \\
\text { покупців } & \text { наявних }\end{array}$ \\
\hline & Переконання & $\begin{array}{l}\text { 50\% споживачів } \\
\text { віком від } 15 \text { до } 49 \text { р. }\end{array}$ \\
\hline & Стимулювання & $\begin{array}{l}\text { 30\% споживачів } \\
\text { віком від } 15 \text { до } 49 \text { р. }\end{array}$ \\
\hline
\end{tabular}

Звичайно цілей маркетингових комунікацій є надзвичайно багато i вони різняться в залежності від об’єкту. Головне завдання на даному етапі з'ясувати їх наявність та відповідність цілям маркетингу.

При проведенні маркетингового аудиту необхідно визначити комунікативний ефект реклами, тобто фактичний вплив реклами на рівень обізнаності споживачів про товар чи про саме підприємство-виробника.

Існують такі методи попереднього оцінювання реклами [2]: пряма оцінка; портфельна перевірка; лабораторні дослідження; метод експертних оцінок.

Після виходу реклами теж необхідно провести маркетинговий аудит.

На вибір комунікативних інструментів в значній мірі буде впливати врахування типу ринку, на якому працює підприємство. За даними досліджень, комунікаційні пріоритети компаній на межі століть виглядають наступним чином (див. табл. 3) [1]. 
Таблиия 3

Значення інструментів маркетингових комунікацій при просуванні споживчих товарів і товарів виробничого призначення

\begin{tabular}{|c|c|c|}
\hline $\begin{array}{c}\text { Основний акцент } \\
\text { маркетингових } \\
\text { комунікацій }\end{array}$ & Споживчий товар & $\begin{array}{c}\text { Товар виробничого } \\
\text { призначення }\end{array}$ \\
\hline Реклама & $* * *$ & $* *$ \\
\hline Стимулювання збуту & $* * *$ & $* * *$ \\
\hline Паблік рілейшнз & $* *$ & $* * * *$ \\
\hline Особистий продаж & $*$ & \\
$*$ - маловагоме значення; & & \\
$* *-$ доволі вагоме значення; & & \\
$* * *-$ досить вагоме значення; & & \\
$* * *-$ дуже вагоме значення.
\end{tabular}

Залежно від цілей організаторів комунікаційної кампанії ефекти бувають: функціональними (результат відповідає меті), дисфункціональними (результат не відповідає меті) і афункціональними (результат не має відношення до мети) [7].

Визначивши бюджет на комунікації, необхідно вирішити питання розподілу коштів між основними інструментами просування. Як правило, способи розподілу бюджету сильно відрізняються навіть в рамках підприємств однієї галузі [3].

Інструменти просування. Кожний засіб просування відрізняється як унікальними характеристиками, так і відповідними їм витратами.

Реклама використовується для створення довгострокового іміджу продукту. Реклама - це ефективний спосіб досягнення територіально розкиданих покупців. Деякі форми реклами (наприклад, на телебаченні) вимагають виділення значних коштів, інші (реклама в газетах) - коштують значно дешевше.

Стимулювання збуту. Інструменти стимулювання збуту (купони, конкурси, премії та подібні заходи) дуже різні і володіють трьома перевагами: комунікативними (привертають увагу цільової аудиторії i, як правило, містять інформацію, що підводить споживача до товару); спонукальними (містять знижку або стимул, яка представляє цінність для споживача); запрошеннями (містять запрошення, щоб негайно укласти угоду або зробити покупку). Заходи щодо стимулювання збуту використовуються для короткострокового впливу, наприклад, для підкреслення вигідності ринкової пропозиції з метою різкого збільшення обсягу продажів.

Зв'язки 3 громадськістю. Привабливість зв'язків з громадськістю базуються на трьох положеннях: висока довіра (повідомлення у випуску новин і статті про те, що можливості продукту більш авторитетні, ніж реклама, і користуються великою довірою); можливість застати покупця зненацька (використовувані методи дозволяють досягти потенційних споживачів, які уникають контактів 3 торговими представниками та рекламою); посилення враження (можливість посилити враження про компанію або ії продукт).

Особисті продажі. Особисті продажі володіють трьома відмінними 
властивостями: особистий контакт (безпосередня інтерактивна взаємодія двох або більше осіб); культура відносин (в ході особистих продажів розвиваються різні типи відносин - від формального спілкування «продавець-покупець» до встановлення міцних дружніх зв'язків); відповідна реакція (покупець відчуває деякий обов'язок вислухати пропозицію і відреагувати на неї).

Наступний інструмент маркетингових комунікацій, який широко використовується в маркетинговій діяльності підприємств та організацій - це заходи стимулювання збуту.

Для аналізу комунікативної результативності можна скористатися існуючими моделями ієрархії результатів (модель AIDA, модель Левіджа і Стейнера, модель DAGMAR, модель Говарда і Шета та ін.), які пояснюють порядок ментальних стадій, через які проходить покупець в процесі руху до покупки товару [4].

Аналіз обізнаності, сформованої завдяки маркетинговим комунікаціям, можна також проводити з використанням підходів, що застосовуються в аналізі економічних результатів: порівняння рівня обізнаності до початку та на кінець комунікативної активності або ж з використанням контрольних та тестованих ринків. Аналогічні підходи можуть бути використані i в процесі аналізу результативності формування необхідного іміджу та створенні позитивного ставлення.

Отже, результативність комунікацій в організації в цілому визначається трьома основними факторами: відкритий менеджмент; усвідомлення менеджментом цінності і необхідності комунікацій з персоналом; кваліфікований i досвідчений менеджер комунікацій, що володіє сучасними технічними ресурсами.

Кожна характеристика повинна виражатися в конкретних показниках. Найлегше 3 характеристикою витрат (в гривнях, в кількості обладнання, в людино-годинах трудовитрат i т. д.), так як вони легше за все піддаються кількісному рахунку [4].

Дещо складніше 3 показниками цілей $\mathrm{i}$ потреб, але i для них $\epsilon$ характеристики, наприклад, ті, які мають кількісне вираження: інформування громадськості; розвиток мотивації персоналу; взаєморозуміння між фірмою і iii соціальним середовищем і т.д. -

Оскільки в аналізі ефективності багато що залежить від первинної бази порівняння, то зміни, що виникають внаслідок роботи фахівця з комунікаційного менеджменту, слід зіставляти по можливості з чіткими і систематизованими уявленнями і характеристиками положення справ [7].

Результати комунікаційної кампанії оцінюються в залежності від того: чи отримали цільові групи спрямовані їм повідомлення; чи вдалося привернути увагу до цих повідомлень; зрозумілий сенс повідомлення; чи зберегли цільові групи ці повідомлення в будь-якому вигляді або формі.

Методи, які часто використовуються для вимірювання результатів, 
включають: кількісні дослідження (особисто, по телефону, поштою, факсом, електронною поштою, через Інтернет, в громадських місцях і т.д.); цільові групи; дослідження відносин вибіркових аудиторій; дослідження до / після отримання тесту (наприклад, опитування «до» і «після»); спостереження, участь; i / або методи рольових ігор; багатовимірні дослідження.

При аналізі ефективності реалізації конкретних програм, проектів та акцій важливо оцінити, що саме запам'ятали люди, у скількох людей і як змінилося ставлення до фірми і відповідну поведінку.

Наймолодшою сферою комунікативної діяльності в Україні $\epsilon$ паблік рілейшнз (PR). В процесі його аналізу, як зазначають фахівці [4, с. 237], слід оцінити наступне: яку репутацію має фірма у зовнішньому оточенні та серед своїх працівників?; які люди чи групи людей здійснюють найбільший вплив на репутацію фірми?; які масштаби популярності фірми: локальні, національні, міжнародні?; які асоціації викликає дана фірма?; чи має фірма на даний момент розроблені PR-програми?

Таким чином, кожний інструмент маркетингових комунікацій додатково до загальної методики аналізу повинен бути проаналізований з врахуванням його специфіки та особливостей.

Без грамотного управління комунікаціями на основі поєднання системного та стратегічного підходів неможливо виживання підприємства в конкурентному полі. Тільки усвідомлення керівництвом організації даного факту створить умови для використання концепції комунікаційного менеджменту в практиці.

При цьому неминуче подолання певних психологічних бар'єрів як самими керівниками, так і співробітниками організації, а також можливих труднощів організаційного та фінансового характеру. Але доцільність такого роду зусиль не викликає сумніву: вже сьогодні очевидно, що оволодіння комунікаційним інструментарієм - одна 3 передумов ефективного управління сучасною організацією.

Висновки. Аудит маркетингу представлений як системний процес всебічного аналізу ефективності роботи комплексу маркетингу підприємства. Під системним підходом до проведення аудиту маркетингу розуміють наявність $\mathrm{i}$ послідовність проведення адміністративних і аналітичних процедур, методів отримання аудиторських доказів за допомогою організації інформаційних потоків отримання необхідної інформації. Отримані в роботі результати, висновки та сформульовані пропозиції $\epsilon$ певним внеском у розвиток теорії і практики управління підприємствами i, зокрема, управління ефективністю їх комунікативної маркетингової діяльності. Використання в практичній діяльності маркетологів результатів проведеної класифікації теоретико-методичних підходів до системної оцінки ефективності комунікативного менеджменту підприємства підвищить рівень наукової обгрунтованості прийнятих рішень в сфері управлінського маркетингу. 


\section{Лimepamypa:}

1. Артур А. Томпсон-мл. и А. Дж. Стрикленд III. Стратегический менеджмент. Концепции и ситуации для анализа. М.: Вильяме, 2007 г. - 928 с.

2. Беляевский И.К. Маркетинговое исследование: информация, анализ, прогноз. М.: Финансы и статистика, 2002. - 320 с.

3. Данченок Л.А. Маркетинговое ценообразование: политика, методы, практика / Л.А. Данченок, А.Г. Иванова. М.: Эксмо, 2006. - 464 с.

4. Дерев'янченко Т.Є. Маркетинговий аудит. Навчально - методичний посібник для самостійного вивчення дисципліни. - К.:КНЕУ, 2007. - 224 с.

5. Келлер К.Л. Маркетинг менеджмент / К.Л. Келлер, Ф. Котлер. - 12 изд. - СПб.: Питер, 2008. $-816 \mathrm{c}$.

6. Китова О.В. Управление эффективностью маркетинга: методология и проектное моделирование / О.В. Китова. - РЭА им. Г.В. Плеханова.: Собор, 1999. - 160 с.

7. Яшева Г.А. Эффективность маркетинга: методика, оценки и результаты // Витеб. гос. тех. ун-т, каф. коммерческой деятельности. - Режим доступа http://www.cfin.ru/press/practical/ 2003-08/02.shtml/

\section{References:}

1. Artur A., Tompson-ml., \& A. Dzh. Striklend III (2007). Strategicheskiy menedzhment. Kontseptsii i situatsii dlya analiza [Strategic management. Concepts and situations for analysis]. M.: Vil'yame, 928 [in England].

2. Belyayevskiy, I.K. (2002). Marketingovoye issledovaniye: informatsiya, analiz, prognoz [Marketing research: information, analysis, forecast]. M.: Finansy i statistika, 320 [in Russian].

3. Danchenok, L.A., \& Ivanova, A.G. (2006). Marketingovoye tsenoobrazovaniye: politika, metody, praktika [Marketing pricing: policy, methods, practice]. M.: Eksmo, 464 [in Russian].

4. Derev'yanchenko, T.Ê. (2007). Marketingoviy audit. Navchal'no - metodichniy posíbnik dlya samostíynogo vivchennya distsiplíni [Marketing audit. Educational - methodical manual for independent study of the discipline]. K.:KNEU, 224 [in Ukrainian].

5. Keller, K.L. \& Kotler, F. (2008). Marketing menedzhment. 12 izd. SPb.: Piter, 816 [in England].

6. Kitova, O.V. (1999). Upravleniye effektivnost'yu marketinga: metodologiya i proyektnoye modelirovaniye [Management of marketing efficiency: methodology and project modeling]. REA im. G.V. Plekhanova.: Sobor, 160 [in Russian].

7. Yasheva, G.A. (2003). Effektivnost' marketinga: metodika, otsenki i rezul'taty [Marketing efficiency: methods, evaluations and results]. Viteb. gos. tekh. un-t, kaf. kommercheskoy deyatel'nosti. - Vitebsk. state those. University, Dept. commercial activity. Retrieved from http://www.cfin.ru/press/practical/ 2003-08/02.shtml/ [in Russian]. 